Southern Illinois University Carbondale

OpenSIUC

Publications

Fisheries and Illinois Aquaculture Center

9-2007

\title{
Sources of Nonnative Centrarchids in the Upper Colorado River Revealed by Stable Isotope and Microchemical Analyses of Otoliths
}

Gregory W. Whitledge

Southern Illinois University Carbondale

Brett M. Johnson

Colorado State University - Fort Collins

Patrick J. Martinez

Colorado Division of Wildlife

Anita M. Martinez

Colorado Division of Wildlife

Follow this and additional works at: http://opensiuc.lib.siu.edu/fiaq pubs

(C) by the American Fisheries Society 2007

Published in Transactions of the American Fisheries Society, Vol. 136, Issue 5 (September 2007) at doi: 10.1577/T06-045.1

\section{Recommended Citation}

Whitledge, Gregory W., Johnson, Brett M., Martinez, Patrick J. and Martinez, Anita M. "Sources of Nonnative Centrarchids in the Upper Colorado River Revealed by Stable Isotope and Microchemical Analyses of Otoliths." (Sep 2007).

This Article is brought to you for free and open access by the Fisheries and Illinois Aquaculture Center at OpenSIUC. It has been accepted for inclusion in Publications by an authorized administrator of OpenSIUC. For more information, please contact opensiuc@lib.siu.edu. 


\title{
Sources of Nonnative Centrarchids in the Upper Colorado River Revealed by Stable Isotope and Microchemical Analyses of Otoliths
}

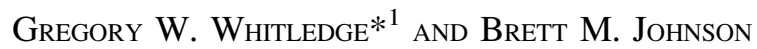 \\ Department of Fish, Wildlife, and Conservation Biology, Colorado State University, \\ 1474 Campus Delivery, Fort Collins, Colorado 80523-1474, USA \\ Patrick J. Martinez and Anita M. Martinez \\ Colorado Division of Wildlife, 711 Independent Avenue, Grand Junction, Colorado 81505, USA
}

\begin{abstract}
Nonnative fishes represent a significant impediment to the recovery of imperiled fishes, including those endemic to the Colorado River in the southwestern United States. Efforts to control nonindigenous fish abundance in the upper Colorado River basin have been unsuccessful owing in part to lack of knowledge regarding nonnative fish recruitment sources. We determined the source habitat (floodplain pond versus riverine habitats) for nonnative centrarchid fishes (largemouth bass Micropterus salmoides, green sunfish Lepomis cyanellus, bluegill L. macrochirus, and black crappie Pomoxis nigromaculatus) in the upper Colorado River using stable hydrogen isotopic composition $(\delta \mathrm{D})$ and strontium : calcium (Sr:Ca) ratios in fish otoliths as natural markers of environmental history. Stable hydrogen isotope analysis revealed that $59 \%$ of centrarchids exhibited the otolith core signatures expected for riverine-origin fish, while $22 \%$ had emigrated from floodplain ponds and $19 \%$ were of uncertain origin. Strontium : calcium ratio data were consistent with the $\delta \mathrm{D}$ assays and indicated that relatively few fish immigrated to the river from high-salinity habitats. Black crappie was the only species that originated primarily from floodplain ponds. Efforts to control the abundance of most of the fishes included in this study should be concentrated in riverine habitats given the hydrologic conditions (below-average river discharge) present during our study. However, the proportion of pond-origin fish increased with fish age, which, coupled with historical river discharge data, suggested that floodplain pond contributions to riverine nonnative fish populations fluctuate with the interannual variations in flow regime and river-pond connectivity. Our results are the first to demonstrate the utility of $\delta \mathrm{D}$ as a natural marker of fish environmental history that will probably provide valuable insights into the management of fish in other environments.
\end{abstract}

The introduction or invasion of nonnative fishes is a major contributing factor in the decline of native fish faunas (Courtenay 1995; Rahel 2002), including that of the Colorado River (Tyus and Saunders 2000). Over the past century, more than 50 species of nonnative fishes have become established in the Colorado River basin (Rinne and Minckley 1991). Centrarchid fishes in particular are considered major predatory or competitive threats to native fishes of the Colorado River drainage (Tyus and Saunders 2000), including four federally endangered species (bonytail Gila elegans, Colorado pikeminnow Ptychocheilus lucius, humpback chub G. cypha, and razorback sucker Xyrauchen texanus). Within the upper basin of the Colorado River an intensive endangered fish recovery program has

\footnotetext{
* Corresponding author: gwhit@siu.edu

${ }^{1}$ Present address: Fisheries and Illinois Aquaculture Center, Department of Zoology, Southern Illinois University, Carbondale, Illinois 62901-6511, USA.
}

Received February 21, 2006; accepted April 16, 2007 Published online July 26, 2007 been in place since 1988 and over US $\$ 81,000,000$ was spent during 1989 to 1900 (USFWS 2004), but many populations of these native fishes have continued to decline.

Four habitat types have been identified in the upper Colorado River basin in the area designated as critical habitat for federally endangered fishes: (1) the main river channel, (2) associated backwaters, (3) beaverimpounded backwaters (these three habitats will hereafter be collectively referred to as riverine habitats), and (4) floodplain ponds. The large number of potential sources and the inability to determine specific habitats where nonnative fishes are reproducing and recruiting has been a vexing problem for managers. Control of nonnative fishes has been a recovery program goal since 1996, but control efforts have been unsuccessful. Recent work (Martinez 2004) focused on chemical removal and physical isolation of nonnative centrarchids in floodplain ponds under the assumption that these habitats contributed the bulk of the centrarchids to the Colorado River (Tyus and Saunders 2000). Unfortunately, there was no evidence 
that abundance of nonnative fishes in the river was affected by control efforts in floodplain ponds (Martinez and Nibbelink 2004). Clearly there is a need to learn more about the most important sources of nonnative fishes to the river to maximize the efficacy of control efforts.

Fisheries managers would benefit from knowledge of the origins and movement patterns of nonnative fishes, which could provide insights into the most promising and efficient control strategies. However, a conventional means to determine nonnative fish sources to the upper Colorado River has not been feasible because physical sampling and mark-recapture techniques are impractical given the scale of the problem. In our study area, there are over 400 ponds within the 100-year floodplain, and more than 200 others nearby, many of which are located on private land (Martinez 2004; Martinez and Nibbelink 2004). The advent of stable isotopic and microchemical analyses of otoliths that exploit natural markers reflecting a fish's environmental history throughout its lifetime (Campana and Thorrold 2001) provided an exciting new avenue for the study of nonnative fish sources.

Much of the previous work using otolith microchemistry for studies of fish environmental history has focused on trace element concentrations and isotopic ratios (e.g., strontium: calcium [Sr:Ca], barium: calcium [Ba:Ca], or strontium isotope $\left[{ }^{87} \mathrm{Sr}:{ }^{86} \mathrm{Sr}\right]$ ratios) in estuarine and anadromous fishes (e.g., Thorrold et al. 1998; Limburg 2001; Secor et al. 2001; Kennedy et al. 2002) because large differences in salt- and freshwater chemical composition are reflected and easily detected in otoliths (Graustein 1989; Campana 1999). However, otolith microchemistry and isotopic analysis have also recently proven useful in studies of fish origins and environmental history within freshwater systems (e.g., Kennedy et al. 1997; Wells et al. 2003; Brazner et al. 2004). In this paper, we describe how we used a natural marker (otolith $\mathrm{Sr}: \mathrm{Ca}$ ratio) that has previously been applied to detect residence in environments that differ greatly in salinity (e.g., Kalish 1990; Limburg 2001) in conjunction with the first application of stable hydrogen isotope analysis of otoliths (Whitledge et al. 2006) to determine sources (floodplain pond versus riverine habitats) of nonnative centrarchid fishes, namely, largemouth bass Micropterus salmoides, green sunfish Lepomis cyanellus, bluegill L. macrochirus, and black crappie Pomoxis nigromaculatus, in the upper Colorado River. We also indicate how this information can be used to guide managers seeking to protect and recover the upper Colorado River basin's native fish assemblage.

\section{Study Area}

The study area for this research encompassed a 140$\mathrm{km}$ reach of the upper Colorado River and adjacent floodplain habitats in west-central Colorado from the town of Rifle $\left(39^{\circ} 31.73^{\prime} \mathrm{N}, 107^{\circ} 46.87^{\prime} \mathrm{W}\right)$ downstream to the mouth of Horsethief Canyon $\left(39^{\circ} 10.21^{\prime} \mathrm{N}\right.$, $\left.108^{\circ} 48.87^{\prime} \mathrm{W}\right)$. Horsethief Canyon is approximately 29 river $\mathrm{km}$ ( $\mathrm{rkm}$ ) west of the Gunnison River confluence at Grand Junction, Colorado. Mean annual discharges above and below the Gunnison River confluence are about $82 \mathrm{~m}^{3} / \mathrm{s}$ and $170 \mathrm{~m}^{3} / \mathrm{s}$, respectively, with peak flows usually occurring during late May and June. Canals in the Grand Valley (extending from approximately $24 \mathrm{rkm}$ upstream from Grand Junction to the lower limit of our study area) divert a substantial portion of river water for agricultural and municipal uses during spring, summer, and fall. The river in the study reach is composed primarily of run and riffle habitat with a bed of cobble and gravel. The river's banks and adjacent floodplain are composed of silt and sand with some bank segments modified by levees or rip-rap. Ephemeral, low-velocity backwater habitats are common downstream from islands or at the mouths of secondary channels in braided reaches. Backwaters are small $(<0.3 \mathrm{ha})$ and shallow (maximum depth $<2 \mathrm{~m}$ ) with silt and sand substrate and few or no aquatic macrophytes, although woody debris is sometimes present. Many backwaters and side channels have been dammed by beavers Castor canadensis, forming small impoundments.

More than 400 ponds (mostly farm ponds and gravel pit depressions) occur in the 100-year floodplain of the Colorado River within the study reach; about 350 of these ponds are within the Grand Valley. Ponds sampled for this study had surface areas less than 4 ha and maximum depths less than $5 \mathrm{~m}$. Pond substrates consist of sand and silt with varying quantities of aquatic plants (mainly Chara and Potamogeton spp.) depending on depth, slope, and water clarity. Some ponds are isolated from the Colorado River; others are permanently or periodically connected to the river by irrigation ditches or overland flow during spates. Salinity in many Grand Valley ponds and ditches frequently exceeds 1\%o (Butler and Osmundson 2000); salinities as high as $26 \%$ were measured in conjunction with this study. Elevated salinities are a consequence of irrigation water leaching minerals from Mancos shale, a marine formation that underlies the entire Grand Valley, coupled with high evaporation rates (Butler and Osmundson 2000). Irrigation water also leaches $\mathrm{Sr}$, an element that commonly substitutes for $\mathrm{Ca}$ in otoliths, from Mancos shale. Strontium concentrations are elevated in surface waters receiving irrigation water 
that has percolated through soils derived from Mancos shale and are further increased by evapotranspiration (Gerner et al. 2006).

\section{Methods}

Field sampling.-Water samples for stable hydrogen isotope analysis were collected from 27 floodplain ponds, 19 backwaters not impounded by beavers, 5 beaver-impounded backwaters, and 13 Colorado River main-channel locations. Floodplain ponds were selected based on accessibility and included five sites upstream from the Grand Valley (one every 10-20 $\mathrm{km})$ and at least one site every 4-8 rkm within the Grand Valley. Ponds were also chosen to encompass the full range of river-pond connectivity (isolated, ditch-connected, and periodically connected ponds). River main-channel sampling sites were adjacent to pond sampling locations. Water samples were obtained from backwaters sampled for fish and six additional unimpounded backwater and beaver-impounded backwater habitats. Samples were collected during November 2003, April 2004, and July 2004 to enable assessment of seasonal changes in water stable hydrogen isotopic composition. Water samples were stored in scintillation vials containing minimal air space and sealed with Parafilm to curtail evaporative loss and fractionation (Kendall and Caldwell 1998). Conductivity $(\mu \mathrm{S} / \mathrm{cm})$ and salinity $(\%)$ were measured in conjunction with each water sample using a portable meter.

Centrarchids $(n=282 ; 141$ green sunfish, 94 largemouth bass, 32 bluegills, and 15 black crappies) were collected from 18 backwaters (both beaverimpounded and unimpounded) in the Grand Valley during 2004 by electrofishing. Fish sampling locations were chosen to include backwaters with and without tributaries or inflowing ditches and locations above and below the Gunnison River confluence. Backwaters sampled for fish were dispersed along the $53-\mathrm{km}$ reach of the Colorado River within the Grand Valley; mean distance between backwater sampling sites was 2.8 $\mathrm{rkm}$. An additional 86 centrarchids (46 green sunfish, 25 largemouth bass, 11 bluegills, and 4 black crappies) were collected in the river's main channel throughout the 140-km study reach. Total length of each fish was measured to the nearest $\mathrm{mm}$. Fish were placed on ice immediately after capture and stored frozen until otoliths were removed.

Laboratory procedures.-Sagittal otoliths were removed from fish using nonmetallic forceps, rinsed with distilled water, and stored dry in polyethylene vials until preparation for analysis. From each fish one otolith was analyzed for stable hydrogen isotopic composition; protein was the source of hydrogen analyzed in otoliths. Otoliths less than $2.5 \mathrm{mg}$ used for hydrogen isotope analysis were analyzed whole; otoliths greater than $2.5 \mathrm{mg}$ were ground to obtain a 2$2.5-\mathrm{mg}$ core sample centered on the otolith nucleus with a Dremel rotary tool. Resolution of stable hydrogen isotope analysis using this procedure corresponded to about the first year of a fish's life based on mean \pm SE otolith mass for late age-0 (bluegill, $1.7 \pm$ $0.2 \mathrm{mg}$; green sunfish, $1.8 \pm 0.3 \mathrm{mg}$; and largemouth bass, $1.5 \pm 0.1 \mathrm{mg}$ ) and age- 1 (bluegill, $3.5 \pm 0.2 \mathrm{mg}$; green sunfish, $3.9 \pm 0.4 \mathrm{mg}$; and largemouth bass, 3.1 $\pm 0.4 \mathrm{mg}$ ) fish from our study area aged with otolith annuli counts. The second otolith from each fish was embedded in Epo-fix epoxy, sectioned in a transverse plane using an ISOMET low-speed saw, and polished to reveal annuli. Age was estimated for each fish by counting otolith annuli. Otolith thin sections were prepared for analysis under a class 100 laminar flow hood and handled only with nonmetallic acid-washed forceps. Thin sections were mounted on acid-washed glass slides using double-sided tape, ultrasonically cleaned for $5 \mathrm{~min}$ in ultrapure water and dried for $24 \mathrm{~h}$ under the laminar flow hood. Mounted and cleaned thin sections were stored in acid-washed polypropylene Petri dishes in a sealed container until analysis.

Water and otolith core samples were analyzed for stable hydrogen isotopic composition using a hightemperature conversion elemental analyzer (TC/EA) interfaced with a Thermo Finnigan Delta Plus XL isotope ratio mass spectrometer. Hydrogen isotope ratios are reported in standard $\delta$ notation, defined as the per mille (\%) deviation between the isotope ratios of a sample and a standard (Vienna Standard Mean Ocean Water), that is,

$$
\delta \mathrm{D}=\left[\left(R_{\text {sample }} / R_{\text {standard }}\right)-1\right] \cdot 1,000,
$$

where $R$ represents ${ }^{2} \mathrm{H} /{ }^{1} \mathrm{H}$. The mean coefficient of variation among replicate measurements was $0.7 \%$ for water samples ( $n=2-3$ replicates per sample) and $0.9 \%$ for solid samples ( $n=2$ replicates per sample).

Otolith thin sections were analyzed for ${ }^{88} \mathrm{Sr}$ and ${ }^{44} \mathrm{Ca}$ using a Perkin-Elmer ELAN 6000 inductively coupled plasma mass spectrometer (ICPMS) coupled with a CETAC Technologies LSX-500 laser ablation system. A transect was ablated with the laser on each otolith thin section extending from the otolith nucleus to its edge along the longest axis (beam diameter $=25 \mu \mathrm{m}$, scan rate $=10 \mu \mathrm{m} / \mathrm{s}$, laser pulse rate $=10 \mathrm{~Hz}$, laser energy level $=9 \mathrm{~mJ}$, wavelength $=266 \mathrm{~nm}$ ). A standard developed by the U. S. Geological Survey (MACS-1, $\mathrm{CaCO}_{3}$ matrix) was analyzed every $12-15$ samples to adjust for possible instrument drift. Each sample analysis was preceded by a gas blank measurement. 
Isotopic counts were converted to elemental concentrations $(\mu \mathrm{g} / \mathrm{g})$ after correction for gas blank, matrix, and drift effects. Strontium concentrations were normalized to $\mathrm{Ca}$ concentration based on the consideration of calcium as a pseudointernal standard (Bickford and Hannigan 2005; Ludsin et al. 2006); data are reported as $\mathrm{Sr}: \mathrm{Ca}$ ratios $(\mathrm{mmol} / \mathrm{mol})$ for consistency with published otolith microchemistry literature and reflect differences in $\mathrm{Sr}$ concentration among samples. Mean limit of detection for ${ }^{88} \mathrm{Sr}$ was $0.09 \mu \mathrm{g} / \mathrm{g}$; otolith ${ }^{88} \mathrm{Sr}$ concentrations ranged from 494 to $6,952 \mu \mathrm{g} / \mathrm{g}$. Analytical precision for $\mathrm{Sr}: \mathrm{Ca}$ was $3 \%$ or better. Isotopic intensities from a blank epoxy sample did not exceed background levels for ${ }^{88} \mathrm{Sr}$ or ${ }^{44} \mathrm{Ca}$.

Data analysis and determination of centrarchid origins.-Differences in median water $\delta \mathrm{D}$ values among habitats (floodplain ponds, backwaters, beaver-impounded backwaters, and river main channel) were assessed by means of Kruskal-Wallis analysis of variance (ANOVA) by ranks. This nonparametric procedure was used because water $\delta \mathrm{D}$ values in some habitats were not normally distributed (Shapiro-Wilkes test: $P<0.001$ ) and could not be made so by simple transformations. Possible influences of conductivity, floodplain pond surface area (ha), and mean floodplain pond depth $(\mathrm{m})$ on water $\delta \mathrm{D}$ were assessed using Spearman rank correlation coefficients.

Classification of fish as having floodplain pond or riverine $\delta \mathrm{D}$ signatures in their otolith cores was accomplished with a model that delimited the expected otolith $\delta \mathrm{D}$ values for fish from these two habitat types. To construct our source habitat classification model, the fifth percentile of floodplain pond water $\delta \mathrm{D}$ values $(-116.5 \%)$ and 95 th percentile of riverine water $\delta \mathrm{D}$ values $(-117.2 \%)$ were identified. Expected values $( \pm 2 \mathrm{SE}$ ) for otolith $\delta \mathrm{D}$ were calculated for each of the above water $\delta \mathrm{D}$ cutoff values using a regression model relating water and otolith $\delta \mathrm{D}$ developed with fish of known environmental history (Whitledge et al. 2006). An upper $95 \%$ confidence limit of predicted riverine fish otolith $\delta \mathrm{D}$ and lower $95 \%$ confidence limit for predicted floodplain pond fish otolith $\delta \mathrm{D}$ served as thresholds in the model. Using this model, fish with otolith core $\delta \mathrm{D}$ values of at least $-128.8 \%$ were identified as having a floodplain pond signature during their first year of life, fish with otolith core $\delta \mathrm{D}$ values of at least $-134.2 \%$ possessed a riverine age- 0 signature, and the origin of fish with intermediate otolith core $\delta \mathrm{D}$ values was uncertain. Variance associated with the regression model relating water and otolith $\delta \mathrm{D}$ (Whitledge et al. 2006) was responsible for the small region of overlap in predicted ranges of otolith $\delta \mathrm{D}$ signatures expected for floodplain pond- and riverine-origin fish. The relationship between water and otolith $\delta \mathrm{D}$ values is consistent among the species collected for this study (Whitledge et al. 2006).

Chi-square tests were applied to assess the significance of the differences in relative frequencies of centrarchids with floodplain pond, riverine, and uncertain otolith core $\delta \mathrm{D}$ signatures by species, fish age, and river reach (upstream versus within the Grand Valley, and above versus below the Gunnison River confluence), and between individuals collected from main-channel and backwater habitats. For fish collected in backwaters, a chi-square test was used to evaluate differences in relative frequencies of individuals with pond, riverine, and uncertain otolith core $\delta \mathrm{D}$ signatures with respect to presence or absence of inflowing ditches or tributary washes. Alpha level (0.05) was divided by the number of chi-square tests to account for the possibility of encountering significant outcomes resulting from chance alone. Differences in median total length of fish with pond, riverine, and uncertain otolith core $\delta \mathrm{D}$ signatures were assessed for each species using Kruskal-Wallis ANOVA by ranks. For fish with floodplain pond otolith core $\delta \mathrm{D}$ signatures, pond water $\delta \mathrm{D}$ was back-calculated using a regression model relating water and otolith $\delta \mathrm{D}$ developed with fish of known environmental history (Whitledge et al. 2006).

Otolith $\mathrm{Sr}: \mathrm{Ca}$ ratios complemented otolith $\delta \mathrm{D}$ analysis by identifying fish that previously resided in environments (some ponds, irrigation ditches) whose salinity exceeded that of riverine habitats. A threshold $\mathrm{Sr}: \mathrm{Ca}$ ratio was used to distinguish periods of residence in high-salinity (salinity exceeding that of riverine habitats, high $\mathrm{Sr}: \mathrm{Ca}$ ) versus low-salinity (salinity not exceeding that of riverine habitats, low $\mathrm{Sr}: \mathrm{Ca}$ ) environments. This threshold $\mathrm{Sr}: \mathrm{Ca}$ ratio was defined by an upper $95 \%$ confidence limit predicted for riverine-resident fish $(2.09 \mathrm{mmol} / \mathrm{mol}$, corresponds to a salinity of $1.7 \%$ ) using a relationship between otolith $\mathrm{Sr}: \mathrm{Ca}$ ratio and environmental salinity (Figure 1) and the highest salinity value recorded in riverine habitats in conjunction with water sampling (1.2\%o). The relationship between otolith $\mathrm{Sr}: \mathrm{Ca}$ and salinity was developed using centrarchids collected from locations in which they were known to have lived solely within one water body (isolated ponds in which fish were naturally reproduced and no stocking occurred and stocked ponds with no opportunity for natural immigration). Different species from the same location had statistically indistinguishable otolith $\mathrm{Sr}: \mathrm{Ca}$ ratios (Kruskal-Wallis test: $P=0.29$ ); Sr:Ca varied by less than $0.5 \mathrm{mmol} / \mathrm{mol}$ along laser-ablated transects from otolith core to edge for individual fish. The significant positive relationship between otolith $\mathrm{Sr}: \mathrm{Ca}$ ratio and salinity of ponds in our study area is probably the result 


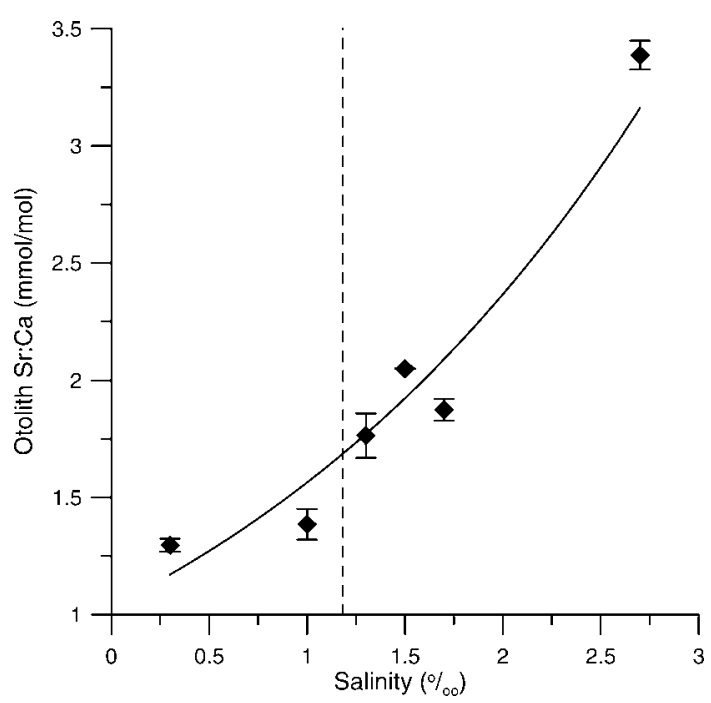

FIGURE 1.-Relationship between otolith strontium : calcium ratio ( $\mathrm{Sr}: \mathrm{Ca}$ ) and environmental salinity developed from centrarchids of known environmental history. Data points are means $\pm \operatorname{SEs}(n=5$ fish per point). The solid line is an exponential function fit to the data $\left(\log _{e}[\mathrm{Sr}: \mathrm{Ca}]=\right.$ $0.413 \cdot$ salinity $\left.+0.034 ; r^{2}=0.92, P<0.005\right)$. The dashed line indicates the upper limit of measured salinity values for riverine habitats.

of higher $\mathrm{Sr}$ concentrations in waters with elevated salinities; concentrations of both $\mathrm{Sr}$ and major salinityinfluencing ions are increased by evapotranspiration and influx of irrigation-derived water that has leached elements from Mancos shale underlying much of our study area (Gerner et al. 2006). Otolith Sr concentration reflects that of the water in which fish live (Howland et al. 2001; Zimmerman 2005); thus, our otolith $\mathrm{Sr}: \mathrm{Ca}$ data are indicative of differences in $\mathrm{Sr}$ concentration among fish (and the environments in which they lived) because we treated $\mathrm{Ca}$ as an internal standard (Bickford and Hannigan 2005; Ludsin et al. 2006). Strontium: calcium ratios for centrarchids of unknown history collected in riverine habitats were calculated based on integrations over entire laser transects when no evidence of fish movement from high-salinity to low-salinity environments was present (initial Sr:Ca $\leq 2.09 \mathrm{mmol} / \mathrm{mol}$; Sr:Ca varied by $<0.5$ $\mathrm{mmol} / \mathrm{mol}$ from beginning to end of transect; Figure $2 \mathrm{~A})$. When evidence of fish emigration from highsalinity environments was present (initial $\mathrm{Sr}: \mathrm{Ca}>2.09$ $\mathrm{mmol} / \mathrm{mol}$, with at least one abrupt decline to a final $\mathrm{Sr}: \mathrm{Ca}$ ratio $<2.09 \mathrm{mmol} / \mathrm{mol}$; Figure 2B, C), Sr:Ca ratios were calculated separately for high-salinity and low-salinity portions of transects. Differences in median otolith core $\mathrm{Sr}$ :Ca ratios among fish with pond, riverine, and uncertain otolith core $\delta \mathrm{D}$ signatures and differences in median otolith core Sr:Ca ratios among species were both assessed using Kruskal-Wallis ANOVA by ranks. Effect of fish age on otolith core Sr:Ca ratio was evaluated using Spearman rank correlation coefficients. Age at immigration was determined for individuals that showed evidence of movement from high-salinity to riverine environments by associating locations of abrupt declines in otolith $\mathrm{Sr}: \mathrm{Ca}$ ratio along laser-ablated transects in relation to annuli.

\section{Results}

Floodplain pond water samples were enriched in ${ }^{2} \mathrm{H}$ compared with water collected from the three riverine habitats (Figure 3); the ranges of floodplain pond and riverine water $\delta \mathrm{D}$ values did not overlap. Median water $\delta \mathrm{D}$ was greater for floodplain ponds compared with beaver-impounded backwaters, unimpounded backwaters, and the river main channel $(P<0.0001)$. Differences in median water $\delta \mathrm{D}$ values among the three riverine habitats were not significant $(P=0.33)$. Absence of overlap in ranges of floodplain pond and riverine water $\delta \mathrm{D}$ values occurred despite incorporation of seasonal variation within habitats. Water $\delta \mathrm{D}$ was positively correlated with conductivity $\left(r_{\mathrm{s}}=0.69, P<\right.$ 0.0001 ), but conductivity ranged from 759 to 37,000 $\mu \mathrm{S} / \mathrm{cm}$ among locations where water $\delta \mathrm{D}$ was greater than $-80 \%$. Floodplain pond water $\delta \mathrm{D}$ was not correlated with mean pond depth $(P=0.65)$ or surface area $(P=0.92)$.

Median otolith core $\delta \mathrm{D}$ was $-125.6 \%$ (inter-quartile range, -122.8 to $-127.6 \%$ ) for fish classified as being of floodplain pond origin (Figure 4). Median otolith core $\delta \mathrm{D}$ was $-138.7 \%$ (inter-quartile range, -136.5 to $-141.4 \%$ ) for fish with riverine otolith core $\delta \mathrm{D}$ signatures. Back-calculation of water $\delta \mathrm{D}$ from otolith core $\delta \mathrm{D}$ (Whitledge et al. 2006) revealed that 68 of the 82 fish (83\%) with floodplain pond otolith core $\delta \mathrm{D}$ signatures emigrated from ponds with water $\delta \mathrm{D}$ values between -100 and $-116 \%$ (mean, $-104.0 \%$; SE, 2.0; range, -29.7 to $-115.8 \%$ ).

Significant differences in the relative proportions of individuals with floodplain pond, uncertain, and riverine otolith core $\delta \mathrm{D}$ signatures were present among species $(P=0.0003)$. Approximately $70 \%$ of largemouth bass and bluegills collected exhibited an otolith core $\delta \mathrm{D}$ signature expected for riverine-resident fish, with $19 \%$ possessing a floodplain pond $\delta \mathrm{D}$ signature in the otolith core, and $10-11 \%$ being of uncertain origin (Figure 5). Slightly more than half of the green sunfish examined displayed a riverine otolith core $\delta \mathrm{D}$ signature. In contrast, the majority of black crappies collected had a floodplain pond otolith core $\delta \mathrm{D}$ signature. 

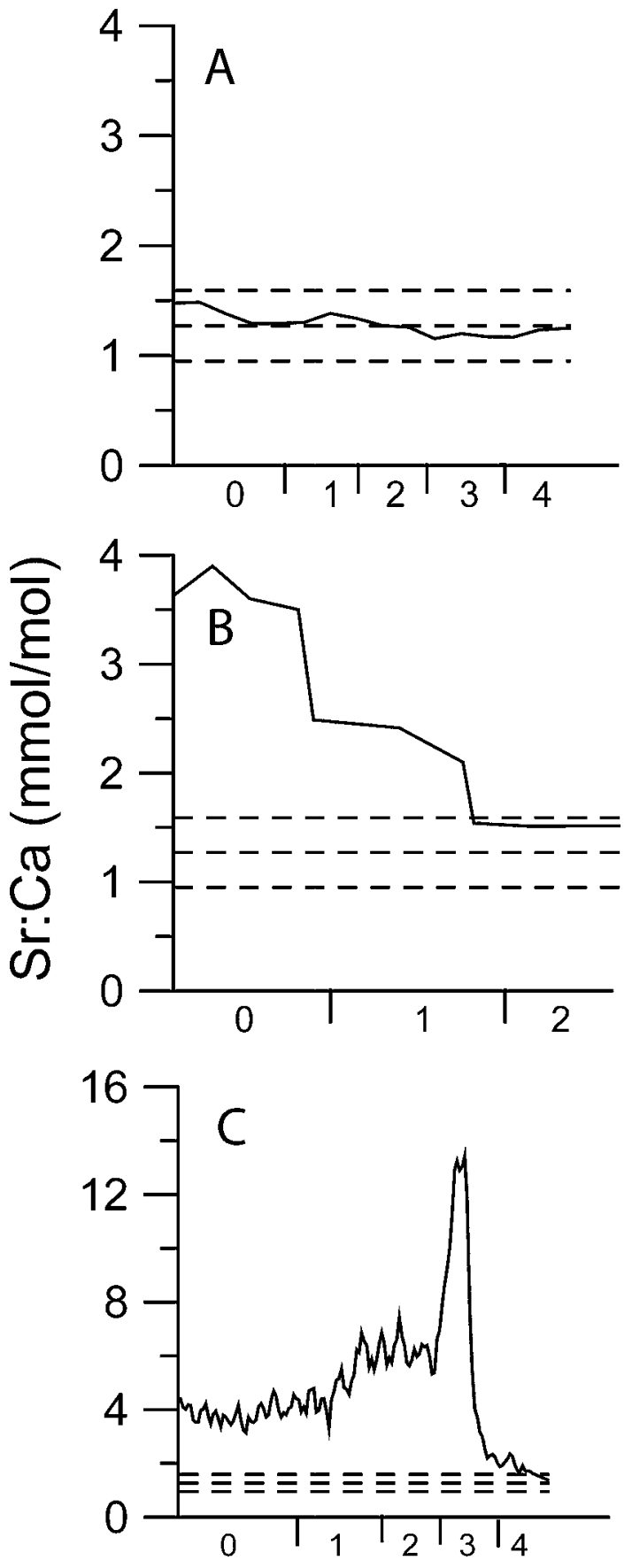

Fish age (yrs)

FIGURE 2.-Representative patterns of otolith strontium: calcium ratios ( $\mathrm{Sr}: \mathrm{Ca}$ ) along laser-ablated transects from the core to the edge of the otolith for individual fish collected from the Colorado River and its backwaters. Data are shown for (A) an age-4 green sunfish, (B) an age-2 green sunfish, and

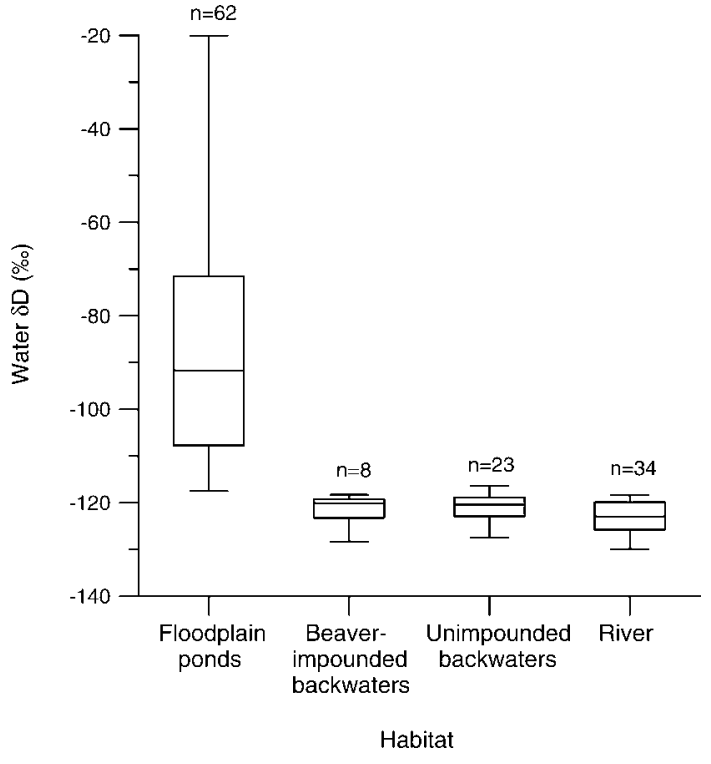

Figure 3.-Box plots of water $\delta \mathrm{D}(\%)$ in floodplain ponds, beaver-impounded backwaters, unimpounded backwaters, and Colorado River main-channel habitats. The median, interquartile range, and range of $\delta \mathrm{D}$ values and the number of samples $(n)$ are shown for each habitat. Samples were collected during November 2003, April 2004, and July 2004.

Sixty of the 82 fish (73\%) with floodplain pond $\delta \mathrm{D}$ signatures in their otolith cores were collected below the Gunnison River confluence. Relative proportions of individuals with floodplain pond, uncertain, and riverine otolith core $\delta \mathrm{D}$ signatures were different above versus below the Gunnison River confluence for both largemouth bass and bluegills $(P<0.001)$; proportions of floodplain pond and uncertain provenance individuals were higher below the Gunnison River confluence than above for both species (Table 1). Relative proportions of individuals with floodplain pond, uncertain, and riverine otolith core $\delta \mathrm{D}$ signatures were not different above versus within the Grand Valley $(P>0.05)$ or among individuals collected in river main-channel versus backwater habitats $(P>$ 0.05 ) for any species. For fish collected in backwaters, presence or absence of direct inflowing ditches or tributary washes did not have an effect on the relative proportions of individuals with floodplain pond, uncertain, and riverine otolith core $\delta \mathrm{D}$ signatures $(P$ $>0.05$ ).

(C) an age-4 black crappie. The dashed lines indicate the mean \pm SD Sr:Ca ratio $(1.27 \pm 0.32 \mathrm{mmol} / \mathrm{mol})$ for fish that possessed a riverine otolith core $\delta \mathrm{D}$ signature $(n=79)$. Note the different scale of the $y$-axis in panel (C). 


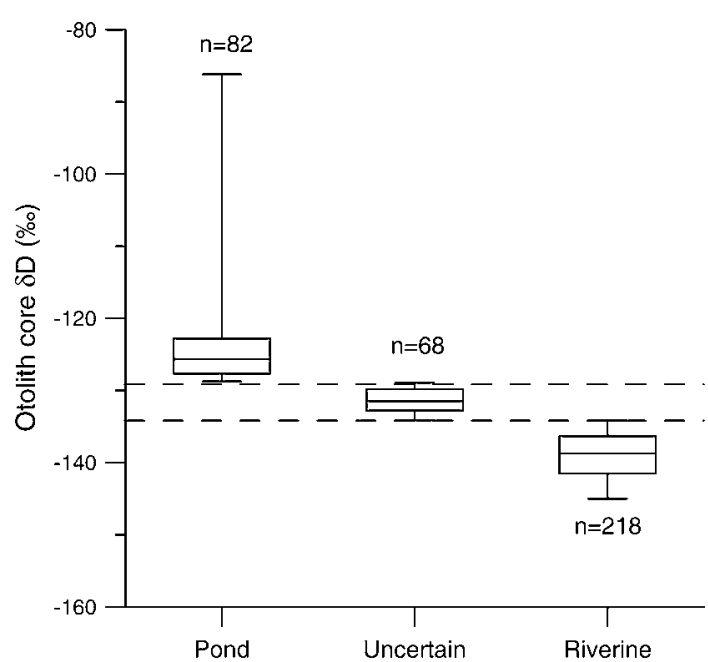

Predicted fish source (based on otolith core $\delta \mathrm{D}$ )

Figure 4.-Box plots of otolith core $\delta \mathrm{D}$ values for fish collected in Colorado River backwater and main-channel habitats. The medians, interquartile ranges, and ranges of otolith core $\delta \mathrm{D}$ values and the number of individuals analyzed $(n)$ are shown for fish classified as being of floodplain pond, uncertain, and riverine origin. The horizontal dashed lines indicate the threshold $\delta \mathrm{D}$ values used to assign the locations of origin to individual fish.

The median length of fish with a floodplain pond otolith core $\delta \mathrm{D}$ signature was greater $(P<0.05)$ than that of fish with a riverine otolith core $\delta \mathrm{D}$ signature for all species except bluegill, whose median lengths were not different $(P=0.55)$ among individuals with floodplain pond and riverine otolith core $\delta \mathrm{D}$ signatures. Relative proportions of individuals with floodplain pond, uncertain, and riverine otolith core $\delta \mathrm{D}$ signatures differed among age classes for all species $(P<0.001)$. The proportion of fish possessing floodplain pond otolith core $\delta \mathrm{D}$ signatures increased and the proportion of individuals exhibiting riverine otolith core $\delta \mathrm{D}$ signatures declined with increasing fish age (Figure 6).

Otolith thin sections from 212 centrarchids collected from Colorado River backwaters were analyzed for $\mathrm{Sr}: \mathrm{Ca}$ ratio using LA-ICPMS. All individuals with riverine otolith core $\delta \mathrm{D}$ signatures $(n=79)$ exhibited otolith core $\mathrm{Sr}: \mathrm{Ca}$ ratios below the upper $95 \%$ confidence limit expected for a riverine-resident fish (Figure 7). Eight fish whose origins were uncertain based on otolith core $\delta \mathrm{D}$ analysis exhibited elevated otolith core $\mathrm{Sr}: \mathrm{Ca}$ ratios characteristic of residence in high-salinity ponds, resolving uncertainty regarding the source of these individuals based on $\delta \mathrm{D}$ analysis alone. Fish with floodplain pond $\delta \mathrm{D}$ signatures in their otolith cores $(n=50)$ exhibited a wide range of otolith core
A Black Crappie $(n=19)$

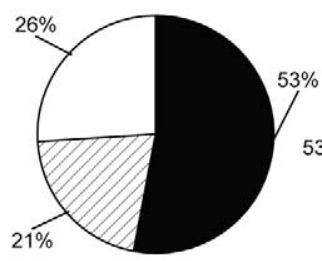

B Green Sunfish $(n=187)$

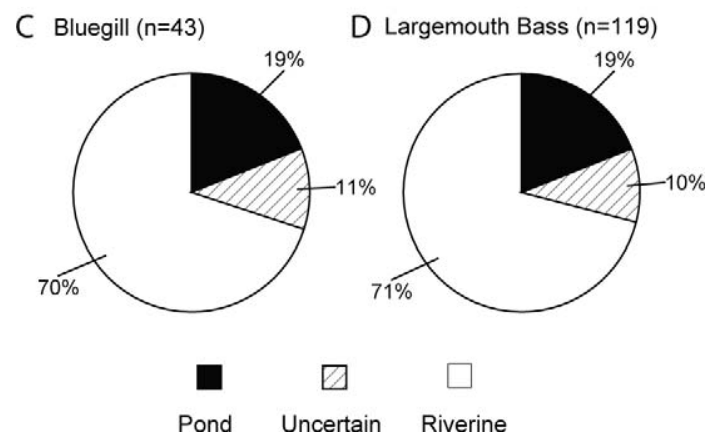

FIGURE 5.-Relative proportions of (A) black crappies, (B) green sunfish, (C) bluegills, and (D) largemouth bass collected in Colorado River backwater and main-channel habitats with floodplain pond, uncertain, and riverine otolith core signatures.

$\mathrm{Sr}: \mathrm{Ca}$ ratios. Median otolith core $\mathrm{Sr}: \mathrm{Ca}$ ratios were higher for fish with floodplain pond (median $\mathrm{Sr}: \mathrm{Ca}=$ $1.51 \mathrm{mmol} / \mathrm{mol}$, corresponding salinity $=0.9 \%$ ) and uncertain (median $\mathrm{Sr}: \mathrm{Ca}=1.42 \mathrm{mmol} / \mathrm{mol}$, corresponding salinity $=0.8 \%$ ) otolith core $\delta \mathrm{D}$ signatures compared with fish with riverine (median $\mathrm{Sr}: \mathrm{Ca}=1.17$ $\mathrm{mmol} / \mathrm{mol}$, corresponding salinity $=0.3 \%$ ) otolith core $\delta \mathrm{D}$ signatures $(P<0.0001)$. Otolith core $\mathrm{Sr}$ :Ca ratio was not associated with fish age for all individuals combined $(P=0.55)$ or for fish with floodplain pond $\delta$ D signatures in their otolith cores $(P=0.48)$. Median otolith core $\mathrm{Sr}: \mathrm{Ca}$ ratio was higher for black crappies compared with the other three species $(P<0.05$; Table 2). Maximum estimated salinity corresponding to otolith core Sr:Ca ratios was highest for black crappies, intermediate for green sunfish and bluegills, and lowest for largemouth bass.

Twenty-two fish exhibited evidence of emigration from high-salinity habitats to the Colorado River based on changes in otolith $\mathrm{Sr}: \mathrm{Ca}$ ratios along laser-ablated transects. Seventeen (77\%) of these individuals were collected below the Gunnison River confluence. Four of the 22 fish immigrated to riverine habitats at age 0,8 immigrated at age 1,5 moved from floodplain pond to riverine habitats at age 2 , and 5 moved to riverine habitats at age 3 . All five fish that showed evidence of 
TABLE 1.-Percentages of largemouth bass and bluegills collected from the Colorado River and its backwaters that possessed otolith core $\delta \mathrm{D}$ signatures (\%o) indicative of floodplain pond, uncertain, and riverine origins for individuals captured above versus below the Gunnison River confluence; $n$ is the number of individuals sampled.

\begin{tabular}{|c|c|c|c|c|c|c|c|c|}
\hline \multirow[b]{2}{*}{ Species } & \multicolumn{4}{|c|}{ Above confluence } & \multicolumn{4}{|c|}{ Below confluence } \\
\hline & $n$ & Pond & Uncertain & Riverine & $n$ & Pond & Uncertain & Riverine \\
\hline Largemouth bass & 47 & 9 & 4 & 87 & 72 & 25 & 15 & 60 \\
\hline Bluegille & 14 & 7 & 0 & 93 & 29 & 24 & 17 & 59 \\
\hline
\end{tabular}

immigration to riverine habitats at age 3 were black crappies.

\section{Discussion}

Utility of Otolith $\delta D$ and Sr:Ca Ratio as Environmental Markers

This study represents the first application of otolith $\delta \mathrm{D}$ analysis to determine the location of origin for individual fish and illustrates the utility of otolith $\delta \mathrm{D}$ as an environmental marker when there are clearly defined spatial differences in water $\delta \mathrm{D}$. Whereas $\delta \mathrm{D}$ has been used to track movements of migratory terrestrial animals on a continental scale (Hobson $2005)$, we showed that $\delta \mathrm{D}$ was capable of discriminating source locations for fish on a much smaller scale (meters to kilometers). Water $\delta \mathrm{D}$ was enriched in ${ }^{2} \mathrm{H}$ in

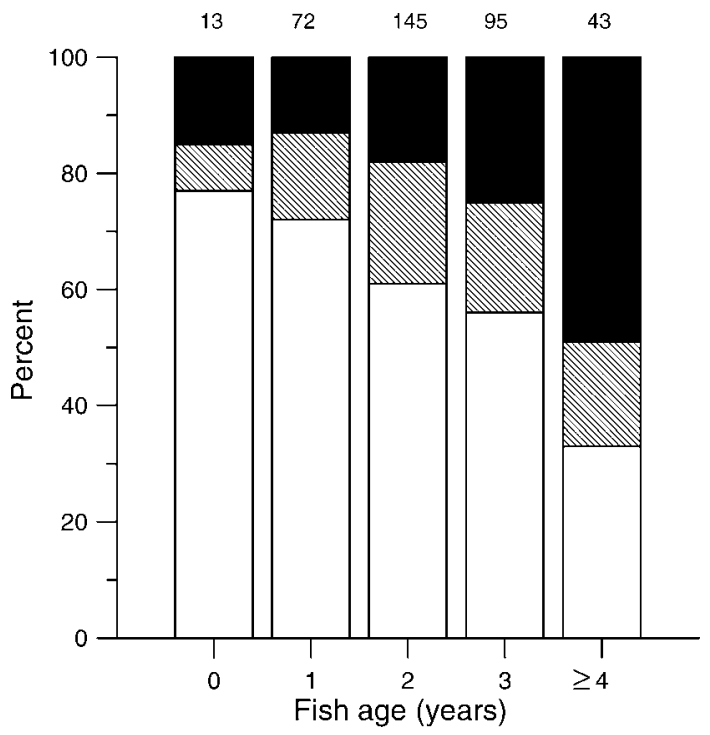

Pond Uncertain Riverine

FIGURE 6.-Relative proportions of centrarchids collected in Colorado River backwater and main-channel habitats with floodplain pond, uncertain, and riverine otolith core signatures, by age-class. The value above each bar is the number of fish analyzed for that age-class. floodplain ponds compared with riverine habitats due to greater opportunity for evaporative fractionation (Kendall and Caldwell 1998) to be expressed in floodplain ponds as a result of their longer water residence time relative to the Colorado River. Differences in water $\delta \mathrm{D}$ among floodplain ponds reflected varying degrees of hydrologic isolation from the Colorado River, but not dissimilarity of pond morphology or conductivity. That conductivity was a relatively poor predictor of water $\delta \mathrm{D}$ values is probably due to the fact that surface water conductivity in our study area is a function of both evaporation and leaching of elements from Mancos shale (Butler and von Guerard 1996), whereas water $\delta \mathrm{D}$ is primarily affected by evaporation. We expect that $\delta \mathrm{D}$ will probably be applicable as an environmental tracer for fish in other locations, particularly in arid or semiarid regions where differential evaporative fractionation has ample opportunity to create spatial variation in water $\delta \mathrm{D}$.

Accurately assigning fish to a source location using otolith microchemistry or stable isotopic composition when the individuals sampled differ in age or year of collection depends on the interannual stability of signatures among locations (Gillanders 2002). Water $\delta \mathrm{D}$ values for 15 samples collected from the Colorado River in our study area at 1-4 month intervals between December 1984 and June 1987 (Coplen and Kendall 2000) were within the range of water $\delta D$ values for riverine habitats measured in this study, suggesting that the $\delta \mathrm{D}$ signature of riverine habitats in our study area is stable among years. No data are available regarding interannual variation of water $\delta \mathrm{D}$ in Grand Valley floodplain ponds. However, overlap between Colorado River and floodplain pond $\delta \mathrm{D}$ signatures would only be expected to occur during periods when river discharge was sufficient to inundate ponds; many ditch-connected ponds are semi-isolated from the river by levees and would not be inundated except during extreme floods. Relatively low variation in $\mathrm{Sr}: \mathrm{Ca}$ ratios along laserablated transects from otolith core to edge $(<0.5 \mathrm{mmol} /$ mol) for floodplain pond fish (age 0 to age 5) of known origin and fish collected from riverine habitats that possessed a riverine otolith core $\delta \mathrm{D}$ signature (age 1 to 


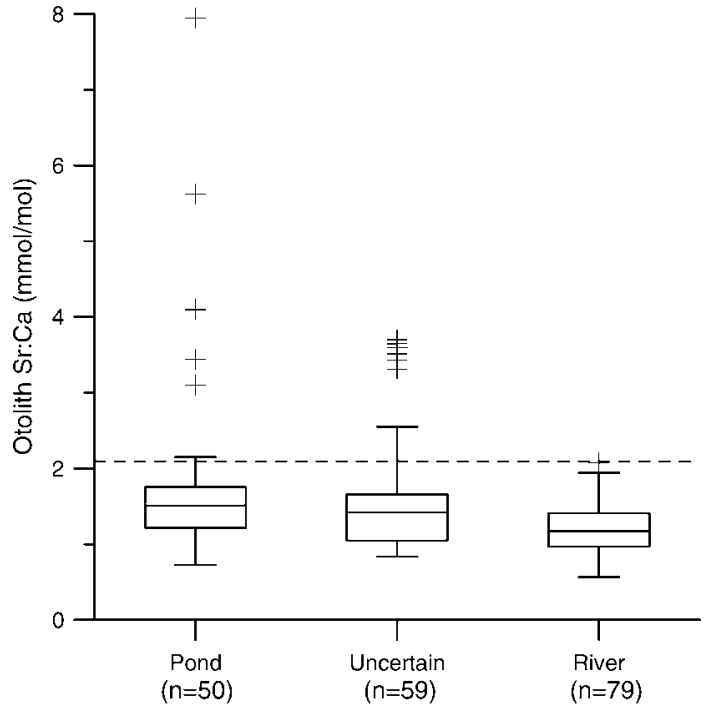

Environmental signature from otolith core $\delta \mathrm{D}$

FIGURE 7.-Box plots showing the medians, interquartile ranges, and ranges of otolith core Sr:Ca ratios for fish with floodplain pond, uncertain, and riverine otolith core $\delta \mathrm{D}$ signatures. Values greater than $1.5 \times$ the interquartile range from the upper or lower quartiles are plotted as outliers (plus signs). The horizontal dashed line indicates the upper $95 \%$ confidence limit of the $\mathrm{Sr}: \mathrm{Ca}$ ratio expected for a riverineresident fish $(2.09 \mathrm{mmol} / \mathrm{mol}) ; n=$ the number of samples analyzed.

age 5) is indicative of interannual stability in water chemistry within habitats and demonstrates that differences in otolith $\mathrm{Sr}: \mathrm{Ca}$ signatures of fish from riverine and high-salinity, floodplain pond habitats (up to $11 \mathrm{mmol} / \mathrm{mol}$ ) can persist among years. These findings are consistent with previous research that demonstrated strong associations between water and otolith microchemistry (Wells et al. 2003) and interannual stability of $\mathrm{Sr}: \mathrm{Ca}$ signatures in some freshwater environments (Zimmerman and Reeves 2002; Wells et al. 2003; Munro et al. 2005; Ludsin et al. 2006).

\section{Centrarchid Source Habitats}

The relative abundance of fish with riverine otolith core $\delta \mathrm{D}$ signatures and $\mathrm{Sr}: \mathrm{Ca}$ ratios indicates that lowvelocity backwater habitats are probably the primary source of three of the four species of centrarchids included in this study. All four species analyzed in this study are associated with low-velocity, river margin habitats (Dettmers et al. 2001; Barko and Herzog 2003) and construct nests in these areas (Pflieger 1997; Scott and Crossman 1998). Black crappie was the only species for which the majority of individuals collected
TABLE 2.-Median and maximum otolith core Sr:Ca ratios $(\mathrm{mmol} / \mathrm{mol})$ and associated salinities (\%o) for black crappies $(n$ $=11)$, bluegills $(n=23)$, green sunfish $(n=104)$, and largemouth bass $(n=74)$. Salinities were calculated from the relationship shown in Figure 1.

\begin{tabular}{lcccc}
\hline \multicolumn{1}{c}{ Species } & $\begin{array}{c}\text { Median } \\
\text { Sr:Ca }\end{array}$ & $\begin{array}{c}\text { Median } \\
\text { salinity }\end{array}$ & $\begin{array}{c}\text { Maximum } \\
\text { Sr:Ca }\end{array}$ & $\begin{array}{c}\text { Maximum } \\
\text { salinity }\end{array}$ \\
\hline Black crappie & 2.33 & 2.0 & 7.95 & 5.0 \\
Bluegill & 1.42 & 0.8 & 3.60 & 3.0 \\
Green sunfish & 1.29 & 0.6 & 3.70 & 3.1 \\
Largemouth bass & 1.23 & 0.5 & 2.15 & 1.8 \\
\hline
\end{tabular}

showed evidence of having emigrated from floodplain ponds, which may be a consequence of their tendency to spawn in or near vegetation (Edwards et al. 1982; Pope and Willis 1997); macrophytes are common in Grand Valley floodplain ponds but are rare or absent in backwaters (Martinez et al. 2001). Black crappie recruitment in many backwaters may also be limited by high turbidity given that negative associations between the density of age-0 Pomoxis spp. and turbidity have been documented in other systems (Mitzner 1991). Our results indicate that efforts to control abundance of largemouth bass, bluegills, and green sunfish in critical habitat for native threatened and endangered fishes should be concentrated in backwaters. Management of black crappie abundance in critical habitat would require an emphasis on restricting escapement from floodplain ponds; however, black crappies are the least numerous centrarchid present in our study area.

Resolution of the approach used for otolith $\delta \mathrm{D}$ analysis corresponded to approximately the first year of a fish's life based on otolith size (mass) for known-age centrarchids collected in our study area. Thus, the possibility exists that individuals that emigrated from floodplain ponds very early during age 0 may have been misclassified as being of riverine origin, because material indicative of riverine residence could dominate the otolith core $\delta \mathrm{D}$ signature under such a scenario. Largemouth bass, bluegills, and green sunfish exhibit parental care (Pflieger 1997), which would probably limit the extent of emigration from ponds by age-0 individuals of these species during their first few weeks of life. Additionally, all four fish that exhibited evidence of immigration to riverine habitats at age 0 based on Sr:Ca analysis by LA-ICPMS (a much higher-resolution technique than the one used for $\delta \mathrm{D}$ ) had a floodplain pond otolith core $\delta \mathrm{D}$ signature (including one age-9 largemouth bass). All 79 individuals that exhibited a riverine otolith core $\delta \mathrm{D}$ signature possessed an otolith core $\mathrm{Sr}: \mathrm{Ca}$ ratio consistent with that expected for riverine-resident fish. Consistency of otolith core $\delta \mathrm{D}$ and $\mathrm{Sr}: \mathrm{Ca}$ results does 
not eliminate the possibility that $\delta \mathrm{D}$ analysis may have misclassified origin of some individuals, as the two markers do not differentiate among identical habitat types in our study area $(\delta \mathrm{D}$ distinguishes floodplain pond- from riverine-resident fish, whereas $\mathrm{Sr}: \mathrm{Ca}$ differentiates between residence in high-salinity habitats, including some floodplain ponds, and low-salinity areas). However, results at least indicate no evidence that mistakes were made. For future applications of otolith $\delta \mathrm{D}$ analysis, advancement of microsampling techniques such as ion microprobe technology (Weber et al. 2002) would be valuable for improving temporal resolution. However, substantial improvement in analytical precision of $\delta \mathrm{D}$ measurements by ion microprobe (currently $\sim 10 \%$ ) would be required.

We were unable to include an independent set of fish of known environmental history to validate our assignments of source habitat for individual fish. We attempted a transplant experiment to verify our ability to recognize the signature of a previously occupied environment in otolith cores by stocking into a fishless isolated pond. Unfortunately, that experiment failed due to a complete summerkill. The availability of fish of known environmental history in our study area is also quite limited given the open, highly connected nature of river-floodplain systems. The source of any fish collected in the Colorado River is inherently unknown, and therefore individuals obtained from there could not be used for model validation. Very few completely isolated floodplain ponds are present in our study area; all of these ponds were sampled for fish that were used in a regression of otolith $\delta \mathrm{D}$ on water $\delta \mathrm{D}$ (Whitledge et al. 2006) that served as the basis for our classification model. Transferring fish from floodplain ponds to cages placed in the Colorado River for the purpose of generating validation data were also impractical given the probabilities of flooding and vandalism.

\section{Directing Centrarchid Control Efforts}

Pinpointing locations within the study area that contribute large numbers of nonnative fish species will be important for directing control efforts to problem areas. The greater proportion of fish with floodplain pond otolith core $\delta \mathrm{D}$ signatures collected below the Gunnison River confluence than above it is not likely the result of the Gunnison River contributing substantial numbers of pond-origin fish to the Colorado River, as the density of ponds along the Gunnison River is relatively low (1.2 ponds/rkm; Martinez and Nibbelink 2004). Rather, the higher incidence of centrarchids emigrating from ponds to the Colorado River below the Gunnison River confluence is probably related to the relatively high density of ponds along the Colorado
River in the Grand Valley downstream from where the Gunnison River enters (6.2 ponds/rkm), coupled with the relative abundance of irrigation ditches and washes that enter the Colorado River downstream from the Gunnison River confluence (Martinez and Nibbelink 2004). Another contributing factor may be that the generally larger, deeper, more structurally complex backwaters found below the Gunnison River confluence may be more attractive to centrarchids or more conducive to their growth or survival than the generally smaller, shallower, and structurally simpler backwaters found above the Gunnison confluence.

Any efforts to control centrarchid escapement from floodplain ponds to the Colorado River should be focused on the reach below the Gunnison River confluence. However, such actions should be secondary to management activities in riverine habitats given that the majority of fish examined in this study exhibited riverine otolith core $\delta \mathrm{D}$ signatures. Placing physical barriers in irrigation ditches and washes represents one possible strategy for controlling centrarchid immigration to critical riverine habitats (Tyus and Saunders 2000). However, such barriers could negatively affect native fishes that also use ditches and washes in our study area (A. Martinez and L. Martin, Colorado Division of Wildlife, personal observation). Physical or chemical control or outlet screening of individual ponds would have less impact on native fishes (Tyus and Saunders 2000; Martinez 2004), but may be impractical for achieving substantial reductions in centrarchid escapement due to the large number of floodplain ponds in the Grand Valley below the Gunnison River confluence, many of which are privately owned. Reinvasion by centrarchids is also common in Grand Valley floodplain ponds in which nonnative fishes had previously been eradicated (Martinez 2004).

The high proportion $(83 \%)$ of pond emigrants that left floodplain ponds with water $\delta \mathrm{D}$ values of no more than $-100 \%$ probably reflects a higher probability of fish immigration to riverine habitats from floodplain ponds that are closely associated with the Colorado River compared with ponds that are more distant from the river. Increased connectivity between large rivers and off-channel floodplain lakes can enhance fish passage between these habitats (Galat et al. 1998). Centrarchids with floodplain pond $\delta \mathrm{D}$ signatures in their otolith cores exhibited a wide range of otolith core $\mathrm{Sr}: \mathrm{Ca}$ ratios, reflecting emigration from ponds with differing salinities (predicted range, $0-5 \%$ ). Most individuals that exhibited evidence of emigration from high-salinity habitats were collected below the Gunnison River confluence, reflecting the relative abundance of high-salinity ponds and washes in that area. 
Significantly higher median otolith core $\mathrm{Sr}: \mathrm{Ca}$ ratio for black crappies compared with the other three species may indicate a greater tendency for black crappies to originate in high-salinity ponds, but our sample size for black crappies was relatively small. Black crappies have been collected in waters having salinities as high as $4.7 \%$ (Edwards et al. 1982), although other centrarchids collected in this study are also at least as salinity tolerant (Musselman et al. 1995; Susanto and Peterson 1996). While results of otolith core $\delta \mathrm{D}$ analyses indicate that any efforts to control centrarchid escapement from floodplain ponds should be directed primarily toward locations closely associated with the river, our findings do not provide any more specific evidence that particular ponds or groups of ponds are disproportionately contributing to centrarchid abundance in riverine habitats. No clear pattern with respect to age at immigration was evident from $\mathrm{Sr}: \mathrm{Ca}$ data. However, our results indicate that centrarchids have the capacity to move into riverine habitats from age 0 to at least age 3 .

Lack of a significant association between the relative frequencies of individuals collected in backwaters with pond, riverine, and uncertain otolith core $\delta \mathrm{D}$ signatures and the presence or absence of direct inflowing ditches or washes suggests that the centrarchids that immigrate to riverine habitats are selecting the best available habitats rather than simply occupying those closest to their point of entry into the river. Species collected in this study are typically associated with structurally complex habitats (Scott and Crossman 1998; Barwick 2004) and tend to be most abundant in backwaters that are large, relatively deep, and possess plentiful cover (Bundy and Bestgen 2001). Control efforts in riverine habitats for centrarchids included in this study should emphasize backwaters that contain abundant structure irrespective of presence or absence of direct tributaries rather than focusing on those with inflowing washes or ditches.

\section{Relation between Fish Age and Source Habitat and Implications for Future Research}

The proportion of centrarchids with floodplain pond otolith core $\delta \mathrm{D}$ signatures increased with fish age, and individuals with floodplain pond otolith core $\delta \mathrm{D}$ signatures had greater median total lengths than fish with riverine otolith core $\delta \mathrm{D}$ signatures for three of the four species examined. These findings may be consequences of differential mortality of riverine- and floodplain pond-origin fish or interannual variation in river hydrology and its potential effects on centrarchid reproduction, larval nursery, and immigration to the river. The upper Colorado River basin has experienced below average precipitation and mean annual discharge was below average from 2000 to 2004 (USGS 2005).
During dry years, decreased river-pond connectivity (Galat et al. 1998) and increased temporal and spatial extent of low-velocity habitat in the river would be expected. Such conditions could be more favorable for centrarchid reproduction and recruitment in riverine habitats due decreased probability of scouring flows and flushing of larvae from nesting sites (Brown and Ford 2002), while simultaneously limiting access to the river for pond-dwelling fish. Warmer temperatures during years of reduced snowmelt runoff may also be more optimal for centrarchid reproduction in the river. Thus, the recent drought may explain why the majority of the smallest youngest fish carried a riverine $\delta \mathrm{D}$ signature in the otolith core.

Age-4 and older fish had the highest proportion of individuals with floodplain pond otolith core $\delta \mathrm{D}$ signatures, and the largest individuals of three species (particularly largemouth bass and black crappie) almost always carried a floodplain pond otolith core $\delta \mathrm{D}$ signature. These results suggest that, although the percentage of pond-origin fish in riverine habitats was relatively low at the time of our collections, it may have been higher before the current drought and could increase again during years with normal or above average precipitation and river discharge. During wetter years, increased river-pond connectivity (Galat et al. 1998) and a reduction in temporal and spatial extent of low-velocity habitat in the river would be expected. These conditions would be anticipated to be detrimental to centrarchid reproduction and recruitment in riverine habitats (Brown and Ford 2002), while enhancing access to the river for pond-dwelling fish. Our results suggest that centrarchid control efforts in the upper Colorado River should be focused on riverine habitats when hydrologic conditions are similar to those during this study, but reevaluation of relative proportions of riverinedwelling centrarchids with pond and riverine otolith core $\delta \mathrm{D}$ signatures is recommended during and immediately following years of above average precipitation and river discharge. Possible effects of increased precipitation on riverine and floodplain pond water $\delta \mathrm{D}$ signatures should be assessed as part of this effort. Such a follow-up study would be useful for determining whether management of centrarchid abundance in critical habitat should always be focused within riverine habitats themselves, or if additional emphasis should be placed on controlling centrarchid escapement from ponds to curtail immigration to riverine habitats during high-water years.

Our findings corroborate those of a few other recent studies that demonstrated that otolith microchemistry and isotopic analysis represent powerful techniques for retrospectively describing the environmental history of fishes that reside solely in freshwaters, including lakes (Joukhadar et al. 2002; Brazner et al. 2004; Munro et al. 
2005; Ludsin et al. 2006), streams (Wells et al. 2003), and small rivers (Bickford and Hannigan 2005). The results of this study demonstrate that otolith elemental and isotopic assays can also be applied to gain valuable insight into fish movement between large rivers and associated lentic floodplain habitats that would be difficult to obtain by other means. The ability to track the movement of relatively large numbers of individual fish between lotic and lentic habitats will probably prove beneficial to management of both native and nonnative fishes in other large river-floodplain ecosystems.

\section{Acknowledgments}

Funding for this research was provided by the Recovery Program for Endangered Fishes of the Upper Colorado River Basin. We thank the U. S. Fish and Wildlife Service office in Grand Junction, Colorado, (especially Bob Burdick) for providing some of the fish used in this study. Hydrogen isotope analyses were performed by the Alaska Stable Isotope Facility (Water and Environmental Research Center, University of Alaska Fairbanks). Dan Reuss (Colorado State University Natural Resources Ecology Laboratory) provided access to the laminar flow hood. We thank Ian Ridley and Alan Koenig (U. S. Geological Survey Mineral Resources Team, Denver, Colorado) for access to the LA-ICPMS laboratory and providing analytical support. We also thank the landowners in the Grand Valley that graciously allowed access to ponds on their property. Three anonymous reviewers provided comments on the manuscript.

\section{References}

Barko, V. A., and D. P. Herzog. 2003. Relationship among side channels, fish assemblages, and environmental gradients in the unimpounded upper Mississippi River. Journal of Freshwater Ecology 18:377-382.

Barwick, D. H. 2004. Species richness and centrarchid abundance in littoral habitats of three southern U.S. reservoirs. North American Journal of Fisheries Management 24:76-81.

Bickford, N., and R. Hannigan. 2005. Stock identification of walleye via otolith chemistry in the Eleven Point River, Arkansas. North American Journal of Fisheries Management 25:1542-1549.

Brazner, J. C., S. E. Campana, and D. K. Tanner. 2004. Habitat fingerprints for Lake Superior coastal wetlands derived from elemental analysis of yellow perch otoliths. Transactions of the American Fisheries Society 133:692-704.

Brown, L. R., and T. Ford. 2002. Effects of flow on the fish communities of a regulated California river: implications for managing native fishes. River Research and Applications 18:331-342.

Bundy, J. M., and K. R. Bestgen. 2001. Evaluation of the Interagency Standardized Monitoring Program sampling technique in backwaters of the Colorado River in the Grand Valley, Colorado. Colorado State University, Larval Fish Laboratory Contribution 119, Fort Collins.
Butler, D. L., and B. C. Osmundson. 2000. Physical, chemical, and biological data for the Uncompahgre project area and the Grand Valley, west-central Colorado, 1993-1998. U.S. Geological Survey, Open-File Report 99-453, Grand Junction, Colorado.

Butler, D. L., and P. B. von Guerard. 1996. Salinity in the Colorado River in the Grand Valley, western Colorado, 1994-1995. U.S. Geological Survey, Fact Sheet FS-21596, Grand Junction, Colorado.

Campana, S. E. 1999. Chemistry and composition of fish otoliths: pathways, mechanisms, and applications. Marine Ecology Progress Series 188:263-297.

Campana, S. E., and S. R. Thorrold. 2001. Otoliths, increments, and elements: keys to a comprehensive understanding of fish populations? Canadian Journal of Fisheries and Aquatic Sciences 58:30-38.

Coplen, T. B., and C. Kendall. 2000. Stable hydrogen and oxygen isotope ratios for selected sites of the U.S. Geological Survey's NASQAN and BENCHMARK surface-water networks. U.S. Geological Survey, OpenFile Report 00-160, Reston, Virginia.

Courtenay, W. J., Jr. 1995. The case for caution with fish introductions. Pages 413-424 in H. L. Schramm, Jr., and R. G. Piper, editors. Uses and effects of cultured fishes in aquatic ecosystems. American Fisheries Society, Symposium 15, Bethesda, Maryland.

Dettmers, J. M., D. H. Wahl, D. A. Soluk, and S. Gutreuter. 2001. Life in the fast lane: fish and food web structure in the main channel of large rivers. Journal of the North American Benthological Society 20:255-265.

Edwards, E. A., D. A. Krieger, M. Bacteller, and O. E. Maughan. 1982. Habitat suitability index models: black crappie. U.S. Fish and Wildlife Service Report FWS/ OBS-82/10.6.

Galat, D. L., L. H. Fredrickson, D. D. Humburg, K. J. Bataille, J. R. Bodie, J. Dohrenwend, G. T. Gelwicks, J. E. Havel, D. L. Helmers, J. B. Hooker, J. R. Jones, M. F. Knowlton, J. Kubisiak, J. Mazourek, A. C. McColpin, R. B. Renken, and R. D. Semlitsch. 1998. Flooding to restore connectivity of regulated large-river wetlands. BioScience 48:721-733.

Gerner, S. J., L. E. Spangler, B. A. Kimball, and D. L. Naftz. 2006. Characterization of dissolved solids in water resources of agricultural lands near Manila, Utah, 2004-2005. U.S. Geological Survey, Scientific Investigations Report 2006-5211, Reston, Virginia.

Gillanders, B. M. 2002. Temporal and spatial variability in elemental composition of otoliths: implications for determining stock identity and connectivity of populations. Canadian Journal of Fisheries and Aquatic Sciences 59:669-679.

Graustein, W. C. $1989 .{ }^{87} \mathrm{Sr} /{ }^{86} \mathrm{Sr}$ ratios measure the sources and flow of strontium in terrestrial ecosystems. Pages 491-511 in P. W. Rundel, J. R. Ehleringer, and K. A. Nagy, editors. Stable isotopes in ecological research. Springer Verlag, New York.

Hobson, K. A. 2005. Using stable isotopes to trace longdistance dispersal in birds and other taxa. Diversity and Distributions 11:157-164.

Howland, K. L., W. M. Tonn, J. A. Babaluk, and R. F. Tallman. 2001. Identification of freshwater and anadromous inconnu in the Mackenzie River system by analysis of otolith strontium. Transactions of the American Fisheries Society 130:725-741. 
Joukhadar, Z., W. P. Patterson, T. N. Todd, and G. R. Smith. 2002. Temperature history of Coregonus artedi in the St. Marys River, Laurentian Great Lakes, inferred from oxygen isotopes in otoliths. Ergebnisse der Limnologie 57:453-461.

Kalish, J. M. 1990. Use of otolith microchemistry to distinguish the progeny of sympatric anadromous and nonanadromous salmonids. U.S. National Marine Fisheries Service Fishery Bulletin 88:657-666.

Kendall, C., and E. A. Caldwell. 1998. Fundamentals of isotope geochemistry. Pages 51-86 in C. Kendall and J. J. McDonnell, editors. Isotope tracers in catchment hydrology. Elsevier, Amsterdam.

Kennedy, B. P., C. L. Folt, J. D. Blum, and C. P. Chamberlain. 1997. Natural isotope markers in salmon. Nature (London) 387:766-767.

Kennedy, B. P., A. Klaue, J. D. Blum, C. L. Folt, and K. H. Nislow. 2002. Reconstructing the lives of fish using $\mathrm{Sr}$ isotopes in otoliths. Canadian Journal of Fisheries and Aquatic Sciences 59:925-929.

Limburg, K. E. 2001. Through the gauntlet again: demographic restructuring of American shad by migration. Ecology 82:1584-1596.

Ludsin, S. A., B. J. Fryer, and J. E. Gagnon. 2006. Comparison of solution-based versus laser ablation inductively coupled plasma mass spectrometry for analysis of larval fish microelemental composition. Transactions of the American Fisheries Society 135:218-231

Martinez, A. M. 2004. An evaluation of nonnative fish control treatments in ponds along the Colorado and Gunnison rivers, 1996-2002. Colorado Division of Wildlife, Final Report, Grand Junction.

Martinez, P. J., B. M. Johnson, and J. D. Hobgood. 2001. Stable isotope signatures of native and nonnative fishes in upper Colorado River backwaters and ponds. Southwestern Naturalist 46:311-322.

Martinez, P. J., and N. P. Nibbelink. 2004. Colorado nonnative fish stocking regulation evaluation. Colorado Division of Wildlife, Final Report, Grand Junction.

Mitzner, L. 1991. Effect of environmental variables upon crappie young, year-class strength, and the sport fishery. North American Journal of Fisheries Management 11:534-542.

Munro, A. R., T. E. McMahon, and J. R. Ruzycki. 2005. Natural chemical markers identify source and date of introduction of an exotic species: lake trout (Salvelinus namaycush) in Yellowstone Lake. Canadian Journal of Fisheries and Aquatic Sciences 62:79-87.

Musselman, N. J., M. S. Peterson, and W. J. Diehl. 1995. The influence of salinity and prey salt content on growth and intestinal $\mathrm{Na}+/ \mathrm{K}+$-ATPase activity of juvenile bluegill, Lepomis macrochirus. Environmental Biology of Fishes 42:303-311.

Pflieger, W. L. 1997. The fishes of Missouri. Missouri Department of Conservation, Jefferson City.

Pope, K. L., and D. W. Willis. 1997. Environmental characteristics of black crappie (Pomoxis nigromaculatus) nesting sites in two South Dakota waters. Ecology of Freshwater Fish 6:183-189.
Rahel, F. J. 2002. Homogenization of freshwater faunas. Annual Reviews in Ecology and Systematics 33:291315.

Rinne, J. N., and W. L. Minckley. 1991. Native fishes of arid lands: a dwindling resource of the desert Southwest. U.S. Forest Service General Technical Report RM-206.

Scott, W. B., and E. J. Crossman. 1998. Freshwater fishes of Canada. Galt House Publications, Oakville, Ontario.

Secor, D. H., J. R. Rooker, E. Zlokovitz, and V. Zdanowicz. 2001. Identification of riverine, estuarine, and coastal contingents of Hudson River striped bass based on otolith elemental fingerprints. Marine Ecology Progress Series 211:245-253.

Susanto, G. N., and M. S. Peterson. 1996. Survival, osmoregulation, and oxygen consumption of YOY coastal largemouth bass, Micropterus salmoides (Lacepède) exposed to saline media. Hydrobiologia 323:119_ 127.

Thorrold, S. R., C. M. Jones, P. K. Swart, and T. E. Targett. 1998. Accurate classification of nursery areas of juvenile weakfish (Cynoscion regalis) based on chemical signatures in otoliths. Marine Ecology Progress Series 173:253-265.

Tyus, H. M., and J. F. Saunders III. 2000. Nonnative fish control and endangered fish recovery: lessons from the Colorado River. Fisheries 25(9):17-24.

USFWS (U.S. Fish and Wildlife Service). 2004. Recovery program overview: Upper Colorado River Endangered Fish Recovery Program. Available: coloradoriverrecovery. fws.gov/Crrpovvu.htm. (August 2005).

USGS (U.S. Geological Survey). 2005. Calendar year streamflow statistics for Colorado: Colorado River near Cameo, CO. Available: nwis.waterdata.usgs.gov/co/ nwis/annual/?site_no=09095500\&agency_cd=USGS. (July 2005).

Weber, P. K., I. D. Hutcheon, K. D. McKeegan, and B. L. Ingram. 2002. Otolith sulfur isotope method to reconstruct salmon (Oncorhynchus tshawytscha) life history. Canadian Journal of Fisheries and Aquatic Sciences 59:587-591.

Wells, B. K., B. E. Rieman, J. L. Clayton, D. L. Horan, and C. M. Jones. 2003. Relationships between water, otolith, and scale chemistries of westslope cutthroat trout from the Coeur d'Alene River, Idaho: the potential application of hard-part chemistry to describe movements in freshwater. Transactions of the American Fisheries Society 132:409-424.

Whitledge, G. W., B. M. Johnson, and P. J. Martinez. 2006. Stable hydrogen isotopic composition of fishes reflects that of their environment. Canadian Journal of Fisheries and Aquatic Sciences 63:1746-1751.

Zimmerman, C. E. 2005. Relationship of otolith strontium-tocalcium ratios and salinity: experimental validation for juvenile salmonids. Canadian Journal of Fisheries and Aquatic Sciences 62:88-97.

Zimmerman, C. E., and G. H. Reeves. 2002. Identification of steelhead and resident rainbow trout progeny in the Deschutes River, Oregon, revealed with otolith microchemistry. Transactions of the American Fisheries Society 131:986-993. 